\title{
Tuberculosis infection in a late-medieval Hungarian population
}

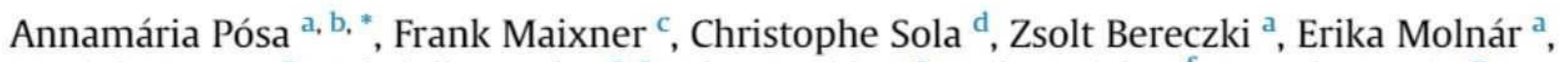 \\ Muriel Masson ${ }^{\mathrm{a}}$, Gabriella Lovász ${ }^{\mathrm{a}, \mathrm{e}}$, Olga Spekker ${ }^{\mathrm{a}}$, Erika Wicker ${ }^{\mathrm{f}}$, Pascale Perrin ${ }^{\mathrm{g}}$, \\ Olivier Dutour ${ }^{\text {h, i }}$, Albert Zink ${ }^{\mathrm{c}}$, György Pálfi ${ }^{\mathrm{a}}$ \\ a Department of Biological Anthropology, University of Szeged, Szeged, Hungary \\ ${ }^{\mathrm{b}}$ Department of Genetics, University of Szeged, Szeged, Hungary \\ ' Institute for Mummies and the Iceman, EURAC Research, Bolzano, Italy \\ d Institut de Génétique et Microbiologie, UMR8621 Equipe IGEPE, Bât 400 Campus d'Orsay, Orsay, France \\ ${ }^{\mathrm{e}}$ Municipal Museum of Subotica, Subotica, Serbia \\ ${ }^{\text {f }}$ Katona József Museum, Kecskemét, Hungary \\ ' Unité de Recherche MIVEGEC, UR 224/IRD, UMR 5290/CNRS, UM1, Université Montpellier 2, Montpellier, France \\ ${ }^{\text {h }}$ Laboratoire d'Anthropologie Biologique Paul Broca, Ecole Pratique des Hautes Etudes, UMR 5199 PACEA, Université de Bordeaux, Pessac, France \\ i Department of Anthropology, University of Western Ontario, Canada
}

Keywords:

Paleopathology

aDNA

Skeletal tuberculosis

Mycobacterium tuberculosis complex

Hungary

\begin{abstract}
S U M M A R Y
The AD $16-17^{\text {th }}$ century skeletal series from Bácsalmás-Óalmás (southern Hungary) has already been the subject of previous paleopathological studies concerning TB-related bone lesions. Due to recent development of macroscopic and molecular diagnostic methods in paleopathology and paleomicrobiology, a five-year international research program was recently started in order to re-evaluate the TB-related lesions in the complete series, comprising 481 skeletons.

The skeletal material of these individuals was examined using macromorphological methods focusing on both classical/advanced stage skeletal TB alterations and atypical/early-stage ТВ lesions. Paleomicrobial analysis was used to study the presence of Mycobacterium tuberculosis complex (MTBC) DNA both in morphologically positive and negative cases. Samples were tested for the repetitive element IS6110 and further characterized by spoligotyping.

In the whole series, 283 possible cases of TB infections were identified based on morphological alterations. Skeletal samples of eighteen individuals, morphologically positive as well as negative cases, were selected for further biomolecular examinations. Among them, seven individuals were PCR positive for the repetitive IS6110 sequence of the MTBC genome.

Compared to the few cases of TB from the Bácsalmás-Óalmás series previously described, a much higher prevalence of MTBC infected skeletons was revealed in this study. The atypical/early stage skeletal lesions occurred significantly more frequently than the so-called classical alterations. Paleomicrobial analysis confirmed a prevalence of MTBC infection nearing $40 \%$ among the selected sample. Preliminary results also indicated better preservation of bacterial DNA in the compact layer of long bones and teeth, while spoligotyping suggested infection by different MTBC pathogens.
\end{abstract}

(1) 2015 Elsevier Ltd. All rights reserved.

\section{Introduction}

Tuberculosis causes about 1.5 million deaths every year, and one-third of the world's current total population may be infected with Mycobacterium tuberculosis [1]. These facts and the millions of

\footnotetext{
* Corresponding author. Department of Biological Anthropology, University of Szeged, Közép fasor 52, H-6726 Szeged, Hungary. Tel./fax: + 36 (62) 544314.

E-mail addresses: posa.annamaria@gmail.com (A. Pósa), olga.spekker@gmail. com (O. Spekker).
}

new TB cases reported by WHO every year have brought renewed attention to the research of this disease and its causative Mycobacterium-species.

Paleopathology provides a vast amount of data on TB and its various osteoarticular occurrence in human skeletal remains found in archeological sites $[2,3]$. The last decade of the $20^{\text {th }}$ century brought major breakthroughs in the paleopathological diagnostics of TB. The first DNA evidence-based molecular (paleomicrobial) study of $M$. tuberculosis infection in old skeletal remains came out in 1993 [4] and was thereafter followed by many [5-7]. 
Paleomicrobial research helps to identify pathogens in ancient human remains, thus providing crucial information on the onset and development of infectious diseases.

The AD $16-17^{\text {th }}$ centuries skeletal series of Bácsalmás-Óalmás (southern Hungary) has been the subject of a wide range of studies including paleopathological investigation. The initial macromorphological research had already suggested the presence of TB infection in this population [8]. Later studies estimated a relatively high frequency of TB but there was no systematic analysis done to evaluate all types of TB lesions. In the first phase of analysis, only classical chronic forms were taken into consideration. A few years later some cases of early or atypical TB infection were identified, and the first ancient DNA (aDNA) results were able to prove that these bones were infected by MTBC, thus confirming that paleomicrobial diagnostic tools could provide evidence for the reliability of early stage or atypical lesions [9].

Following recent developments of macroscopic and molecular diagnostic methods in paleopathology and paleomicrobiology, a five-year international research program was recently started in order to re-evaluate the TB-related lesions in the complete Bácsalmás-Óalmás series. The aim of the project presented here was, for the first time in the history of ancient TB projects in the Bácsalmás series, to study the potential occurrence of TB in the complete series, carrying out a systematic morphological analysis of both early stage/atypical and advanced stage/typical skeletal TB lesions as well as establishing the presence of MTBC aDNA in the skeletons using palemicrobial techniques.

\section{Material and methods}

\subsection{Archaeological background}

The skeletal material came from the Bácsalmás-Óalmás archeological site (AD $16-17^{\text {th }}$ centuries, southern Hungary), excavated in three phases between 1992 and 2003 [10]. This study was carried out on the series of 481 skeletons housed in the collection of the Department of Biological Anthropology at the University of Szeged. The skeletons' state of preservation was exceptionally good, the sandy soil of Bácsalmás (located in the southern part of the Danube-Tisza interfluve) having provided favorable conditions for conservation.

On the basis of the archaeological and historical findings, it was known that this population immigrated from the southern part of Serbia or Montenegro during the Turkish occupation in the AD $16-17^{\text {th }}$ centuries [10]. They did not seem to intermingle with other populations, probably for religious reasons, and their community became closely endogamous $[10]$.

\subsection{Skeletal material and earlier osteological studies}

This study was based on an initial macroscopic morphological examination, complemented with medical imaging techniques in some cases. The paleodemographic analysis revealed 126 males, 113 females and 242 individuals of unknown sex [11].

The skeletal series was very rich in paleopathological cases and previous investigations had already provided a high amount of paleopathological data with some important discoveries [11-16]. Results of these investigations showed that pathological alterations occurred with a high frequency. The abundance of minor skeletal developmental defects could be linked to endogamy, which may indicate that this immigrated population had probably only very limited contact with the autochthonous Hungarian population $[10,14-16]$. Following the first case studies on rheumatological [12] and infectious [8] conditions, several important cases were described, including two cases of ankylosing spondylitis with a possible familial context [14] and the recent discovery of the occurrence of skeletal scurvy in this population [11].

As for TB, presence of this disease was first indicated by morphological data and several cases have been described previously $[8,15,16]$. However, these studies did not consider the entire series and/or focused only on certain types of TB related skeletal lesions. In the course of the investigation presented in this article, lesions possibly associated with MTBC infection were separated into two main groups. In the 'early stage/atypical' group, endocranial-, rib-, vertebral- and long-bone changes probably related to TB were considered [15-17], while the more apparent chronic osseous TB lesions were included in the second 'typical/classical/ advance stage' group $[2,3]$.

\subsection{Selected material for paleomicrobiological analysis}

Eighteen individuals from the complete series of 481 individuals were selected for the molecular investigation, including both morphologically positive (from the aforementioned 283 potentially infected cases) and morphologically negative cases.

In order to compare the preservation of pathogen DNA in different skeletal areas, a total of three samples from each individual were taken from the vertebrae, ribs and long bones. In two cases showing signs of possible TB meningitis (grave no. 264 and grave no. 483) an additional sample was also taken from the cranial bone. Altogether, a total of 56 samples (eighteen individuals with three samples each plus two cranial samples) were utilized in the molecular analysis.

In the second phase of the paleomicrobial investigation, tooth samples were added to the study. This methodological decision was made in order to provide a better estimate of the potential for MTB aDNA preservation in this material. Compared to the abundance of bone samples used in MTB aDNA studies in the literature, there are to date only few references on tooth samples [18-21].

\subsection{Biomolecular analysis}

All aspects of the molecular analysis were conducted at the ancient DNA Laboratory of the EURAC Institute for Mummies and the Iceman, Bolzano, Italy. The sample preparation and DNA extraction were performed in a dedicated pre-PCR area corresponding to the requirements of aDNA studies in order to strictly avoid any contaminations. This includes the use of protective clothing, UV-light exposure of the equipment and bleach sterilization of surfaces, use of PCR workstations and filtered pipette tips. In a designated sample preparation room the outer surface of the bone samples was mechanically removed using a speed rotary tool (Dremel, Konijnenberg, The Netherlands). Cleaned samples were pulverized using a mixer mill (Retsch, Haan, Germany).

DNA extraction was performed with approximately $250 \mathrm{mg}$ of bone powder using the Silica-based DNA extraction method described by Rohland et al. [22] The PCR mix contained $10 \mathrm{mM}$ tris- $\mathrm{HCl}$ (pH 8.3), $50 \mathrm{mM} \mathrm{KCl}, 1.875 \mathrm{mM} \mathrm{MgCl} 2,200 \mu \mathrm{M}$ of each deoxynucleotide trisphosphate, $0.5 \mu \mathrm{M}$ of each primer, $0.1 \mathrm{mg} / \mathrm{ml}$ Bovine serum albumin, $0.05 \mathrm{U} / \mu \mathrm{l}$ AmpliTaq Gold (Applied Biosystems, Foster City, CA, USA) and $2 \mu \mathrm{l}$ of extracted DNA to a final volume of $20 \mu \mathrm{l}$. Polymerase chain reaction was carried out according to the parameters described by Nicklisch and colleagues [23]. The presence of TB DNA was assessed based on a PCR-based assay targeting the MTBC multicopy IS6110 region [24]. For further diagnosis and to possibly subtype the MTBC bacteria, spoligotyping was used on selected specimens performed after Kamerbeek et al. [25] with minor modifications. 


\section{Results and discussion}

Among the examined 481 skeletons, 283 possible cases of TB infection were recorded based on macromorphological data. A very high number of probable early-stage TB lesions were detected. Early-stage spondylodiscitis and arthritis were observed in 24 cases, rib lesions in 190 cases, vertebral hypervascularisation in 101 cases, and endocranial alterations in 73 cases. An association between these lesions was frequently observed, with numerous individuals showing both endocranial alterations revealing possible meningitis and rib periostitis related to probable pleuro/pulmonary infection. As for the association of TB-related lesions and potential stress indicators frequently linked to infectious conditions, evidence of periosteal remodeling were detected in 222 cases, cribra orbitalia in 65 , and cribra cranii in 9 .

Seven out of the eighteen individuals analyzed were positive for the region of IS6110 of M. tuberculosis (Table 1). Four of those positive cases presented morphological evidence of TB.

The seven samples that tested positive for the presence of MTBC DNA are described in more detail below.

Grave no. 18, adult (Adultus, Ad.) male: signs of possible TB spondylitis and superficial vertebral changes (periosteal appositions and remodeling) were observed on two lower thoracic vertebrae (Figure 1) as well as periosteal appositions on several long bones. Signs of probable early stage sacroiliitis were visible bilaterally on the sacroiliac joint surfaces (especially in the iliac region). The eleventh thoracic vertebra of this individual provided a positive aDNA result.

Grave no. 105, adult (Maturus, Mat.) female: skeletal alterations possibly related to an infectious condition were periosteal reactions on four left ribs (the right side ribs showed no pathological alterations), on the left femur and on both tibias. A positive aDNA result was obtained on a rib sample.

Grave no. 264, young child (Infantia I, Inf. I): rib periostitis, signs of diffuse periostitis on the postcranial skeleton, and endocranial lesions probably related to TB meningitis (Figure 2) were observed on the skeletal remains. The most significant feature was the extensive bilateral hypervascularisation of the endocranial surface of the skull together with superficial new bone appositions surrounding the vessel impressions, indicating a severe inflammation of the meninges. A sample from the left humerus yielded a positive aDNA result for the presence of $M$. tuberculosis complex DNA.

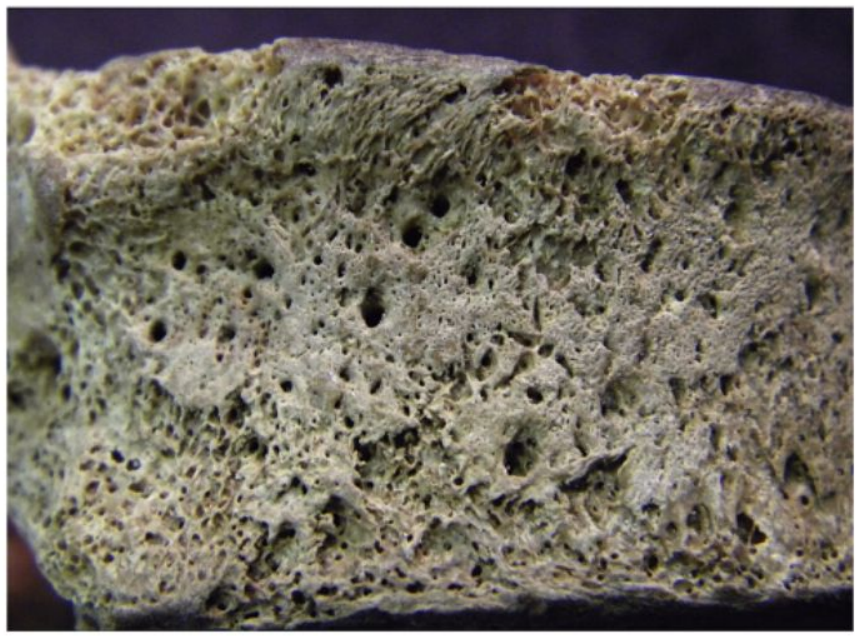

Figure 1. Superficial vertebral changes on a male skeleton (Bácsalmás-Óalmás, Ad. male, Grave no. 18)

Grave no. 391, juvenile (Juvenis, Juv.): signs of severe arthritis (Figure 3) were observed on the right elbow with evidence of osteitis and periostitis in the periarticular region, as well as superficial remodeling and hypervascularisation of several vertebral bodies and long-bone periostitis. A sample taken from the left radius provided a positive DNA result.

Grave no. 438, young child (Infantia I, Inf. I): a sample from the left ulna gave a positive PCR result despite the lack of any pathological features on the skeletal remains.

Grave no. 481, young adult (Adultus, Ad.), female: no macromorphological evidence of infection could be seen but MTB DNA was detected in the bone samples. This was the only case that provided positive PCR results from two of the bone samples (left radius and twelfth thoracic vertebra).

Grave no. 326, adult (Adultus, Ad.), male: no pathological alterations were visible on the skeletal remains. This individual was part of the control group and, despite the lack of bone lesions, yielded positive PCR results. The presence of MTBC DNA in the tooth sample indicated that this individual was infected by a member of the M. tuberculosis complex, but probably died before TB-related osteological lesions could develop.

Table 1

List of osteological samples used for the paleomicrobial studies and their PCR results.

\begin{tabular}{|c|c|c|c|c|c|}
\hline Grave Nr. & Age at death & Sex & Samples & Lesions & $\mathrm{PCR}+$ \\
\hline 18 & Ad & M & $\mathrm{R}$ rib, $\mathbf{R}$ radius, $\mathrm{T} 11$ vertebra & TS?, SVCh, LBP, sacroileitis & PCR+ \\
\hline 105 & Mat & $\mathrm{F}$ & L rib, $\bar{L}$ radius, $L 1$ vertebra & RP, LBP & $\mathrm{PCR}+$ \\
\hline 175 & Ad & $\mathrm{F}$ & Temporal bone, vertebra, radius, rib, tooth & LBP, EL, RP & \\
\hline 208 & Sen & $\mathrm{M}$ & Radius, vertebra, rib, tooth & TS, LBP, RP, sacroileitis & \\
\hline 261 & Inf I & & 3 ribs, L tibia, vertebral fragments & RP, LBP (HOA) & \\
\hline 264 & $\operatorname{Inf} I$ & & $\begin{array}{l}3 \text { ribs, } \mathbf{L} \text { humerus, vertebral fragments, } \\
\text { L temporal bone }\end{array}$ & $\begin{array}{l}\text { RP, EL, LBP (HOA), sinusitis, } \\
\text { EP - scurvy? }\end{array}$ & PCR+ \\
\hline 326 & Ad & M & Radius, vertebra rib, tooth & - & PCR+ \\
\hline 332 & Mat & M & $\mathrm{R}$ rib, $\mathrm{R}$ radius, $\mathrm{T} 11$ vertebra & - & \\
\hline 344 & Juv & & $\mathrm{L}$ rib, $\mathrm{R}$ radius, $\mathrm{T} 11$ vertebra & TA (L elbow), SVCh, EL, CO & \\
\hline 391 & Juv & & $\mathrm{L}$ rib, $\mathbf{L}$ radius, $T 12$ vertebra & TA (R elbow), SVCh, LBP & PCR+ \\
\hline 409 & Juv & & Radius, vertebra, rib, tooth & SVCh, EL, LBP & \\
\hline \multicolumn{6}{|c|}{ 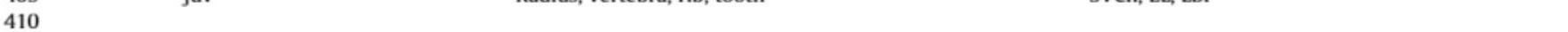 } \\
\hline 416 & Inf II & & $L$ rib, $R$ radius, $T 12$ vertebra & SVCh, LBP! & \\
\hline 423 & $\operatorname{lnf} 1$ & & Temporal bone, tibia, vertebra, rib, tooth & LBP, EL, CO, sacroileitis & \\
\hline 438 & Inf 1 & & 2 ribs, $\mathbf{L}$ ulna, vertebral bodies & - & PCR+ \\
\hline 447 & Mat & M & L rib, $\mathrm{R}$ radius, $\mathrm{T} 11$ vertebra & RRT, LBP, calcified object, sacroiliitis & \\
\hline 481 & Ad & $\mathrm{F}$ & $R$ rib, $L \underline{\text { radius, }} T 12$ vertebra & - & PCR+ \\
\hline 483 & $\operatorname{Inf} I$ & & 2 ribs, L ulna, vertebral fragments, $\mathrm{R}$ temporal bone & RP, EL, LBP, CO & \\
\hline
\end{tabular}

TS: tuberculous spondylitis; TA: tuberculous arthritis; RP: rib periostitis; RRT: rough texture on the visce; SVCh: superficial vertebral changes; EL: endocranial lesions; ESSD: early stage spondylodiscitis; LBP: long bone periostitis; CO: cribra orbitalia.

Bold means: this sample gave positive result. 


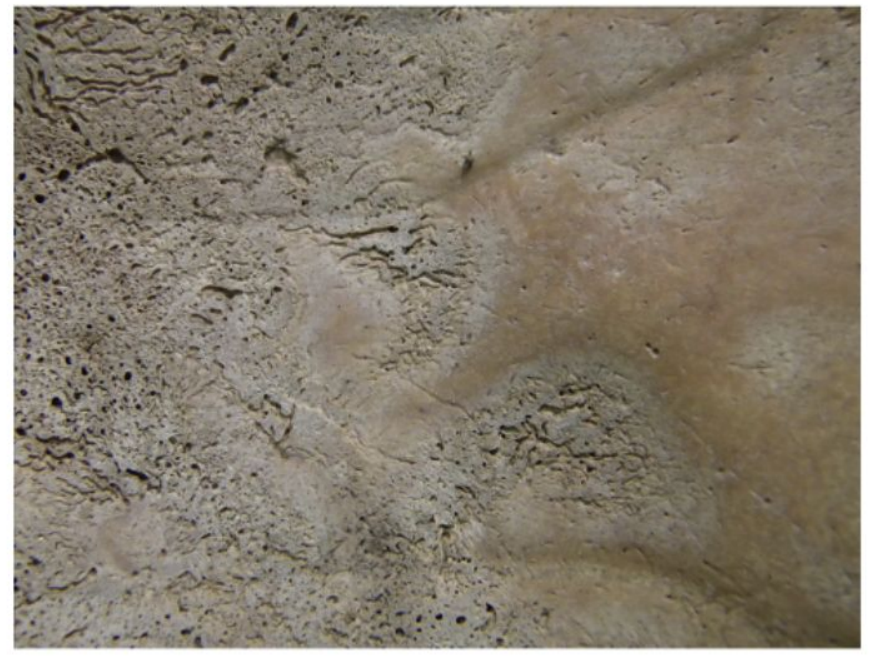

Figure 2. Signs of probable TB meningitis with severe endocranial alterations on a child's skull (Bácsalmás-Óalmás, Inf. I, Grave no. 264).

Six of the cases positive for MTBC were analyzed further by spoligotyping. This analysis revealed different spoligotyping patterns suggesting infection by different MTBC pathogens. Unfortunately, the spoligotypes appeared to be mostly incomplete and further differentiation between the members of the M. tuberculosis complex, such as $M$. tuberculosis or Mycobacterium bovis, could therefore not be obtained.

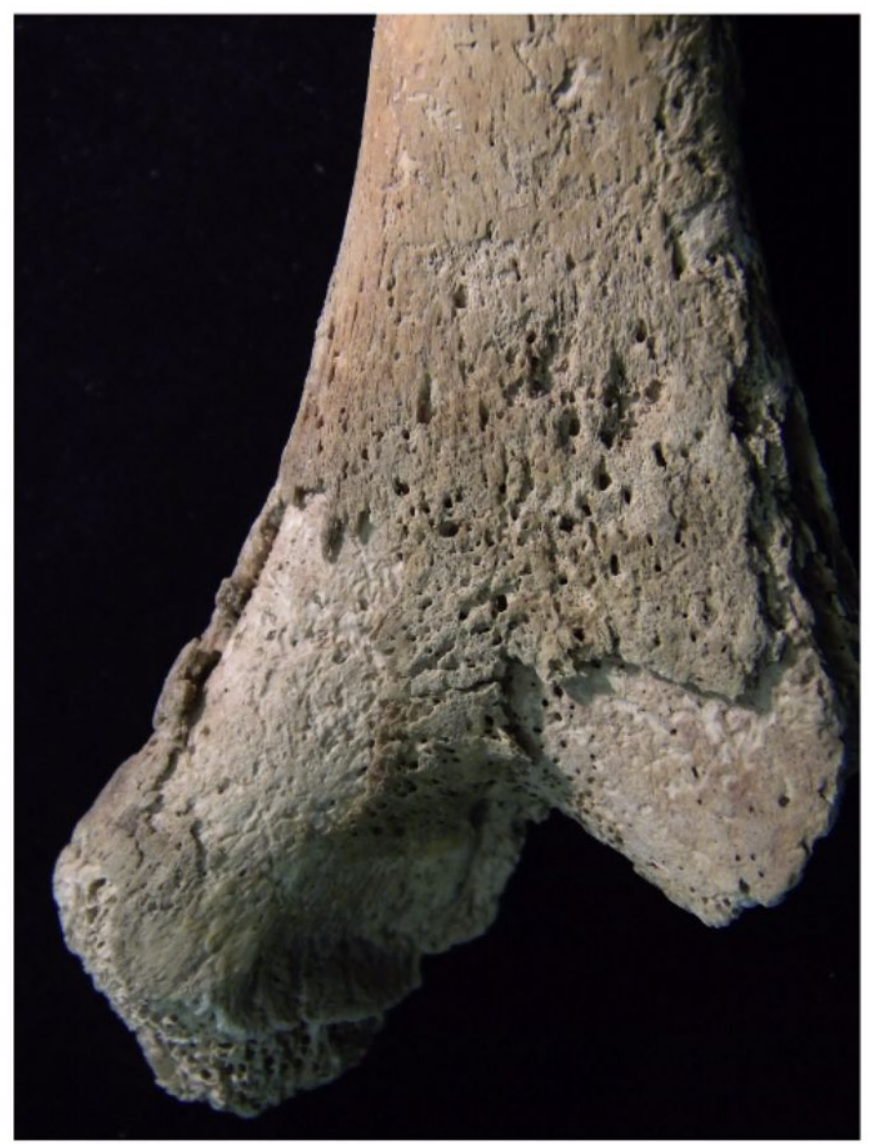

Figure 3. Evidence of osteitis and arthritis on the right elbow of a juvenile skeleton (Bácsalmás-Óalmás, Juv., Grave no. 391).

\section{Conclusions}

The Bácsalmás series had already provided important data during the preliminary aDNA studies of $M$. tuberculosis $[9,26-28]$. MTB aDNA studies had also been more successful with samples from atypical TB cases than with samples from chronic TB forms from the start of this series' investigation [9]. However, earlier paleoepidemiological investigations had indicated a lower prevalence of TB in the Bácsalmás series than was observed in this study. This difference could be explained by the focus of previous studies on typical or advanced-stage forms of skeletal TB only, although the current research team had considered all potential cases of atypical forms as well. In spite of this methodological difference, the very significant amount of potentially infected skeletons (at least half of the recovered individuals) was surprising and would indicate that TB infection was a common occurrence in this endogamous $17^{\text {th }}$ century population. In addition, preliminary results of this study indicated better preservation of mycobacterial DNA in the compact layer of long bones and teeth than in vertebrae or ribs. However, results also highlighted the important role played by the "chance factor" during sampling: of the 64 samples taken from the seven individuals who had tested positive in the PRC analysis, only eight yielded positive results. It is therefore of crucial importance that the complementary results from both biomolecular and morphological analyses are considered together in any TB paleoepidemiological studies. In order to increase the efficiency of molecular methods through better sample selection, multi-site parallel sampling should also be applied to each individual, ideally with at least one sample taken from a long bone's compact layer and one or more taken from the teeth.

At least half of the Bácsalmás skeletal series showed morphological signs of tuberculosis, providing extraordinary potential for a complex investigation of TB paleopathology and leading to the MTB aDNA pilot project presented in this article. Unfortunately, the biomolecular examination of this complete series would be very time-consuming and would require a large amount of funds in order to be completed. Based on this initial project, it is estimated that the biomolecular analysis of at least 2000 samples would be required in order to perform an accurate analysis of such a large skeletal series.

However, this biomolecular pilot study (seven positive samples from eighteen individuals) was able to at least confirm the morphological evidence for a high TB prevalence in this population. The data presented here also clearly supported the results of earlier MTB aDNA works on some of the Bácsalmás cases $[9,15,26]$. The morphological examination yielded numerous cases of early stage TB and the biomolecular analysis provided a much higher prevalence of positive results in this group, strengthening the credibility of these diagnostic categories and their usefulness in paleoepidemiological studies. The spoligotyping picture also suggested infection by different MTBC pathogens, although the precise Mycobacterium (M. tuberculosis, M. bovis, or other) appearing in these samples could not be identified. A repeat of these analyses using the same skeletal samples as well as others from the series has been planned for the sequencing of the remains of mycobacterial DNA in order to clarify the origin of these infections.

\section{Acknowledgment}

This research was supported by the European Union and the State of Hungary, co-financed by the European Social Fund in the framework of TÁMOP-4.2.4.A/2-11/1-2012-0001 'National Excellence Program'. The Hungarian Scientific Research Fund 'OTKA' (OTKA Grant Nos. K78555 and NN 78696) and the "Infectious diseases and environment (MIE)" program, CNRS, France provided 
funding for the macromorphological and aDNA studies. This publication is supported by 'OTKA', Grant number: 78555, the EUHungary co-financed TÁMOP-4.2.2/B-10/1-2010-0012 Project, the MIVEGEC Laboratory and the Université de Montpellier, France.

\section{Funding: None.}

\section{Competing interests: None declared.}

\section{Ethical approval: Not required.}

\section{References}

[1] World Health Organization. Global tuberculosis control: surveillance, planning, financing [WHO report, Geneva]. 2011.

[2] Ortner D]. Identification of pathological conditions in human skeletal remains. New York: Academic Press; 2003. p. 662.

[3] Pálfi Gy, Dutour O, Deák J, Hutás I, editors. Tuberculosis: past and present. Budapest-Szeged: Golden Book Publisher - Tuberculosis Foundation; 1999. p. 608.

[4] Spigelman M, Lemma E. The use of the polymerase chain reaction (PCR) to detect Mycobacterium tuberculosis in ancient skeletons. Int J Osteoarch 1993:3:137-43.

[5] Nerlich AG, Haas C], Zink A, Szeimes U, Hagedorn HG. Molecular evidence for tuberculosis in an ancient Egyptian mummy. Lancet 1997;350:1404.

[6] Zink A, Haas C], Reischl U, Szeimies U, Nerlich AG. Molecular analysis of skeletal tuberculosis in an ancient Egyptian population. J Med Microbiol 2001;50:355-66.

[7] Donoghue HD. Human tuberculosis - an ancient disease, as elucidated by ancient microbial biomolecules. Microbes Infect 2009;11:1156-62.

[8] Molnár E, Pálfi Gy. Probable cases of skeletal infections in the 17th century anthropological series of Bácsalmás(Hungary). Acta Biol Szeged 1994;40:117-33.

[9] Haas C], Zink A, Molnár E, Szeimes U, Reischl U, Marcsik A, Ardagna Y, Dutour O, Pálfi Gy, Nerlich AG. Molecular evidence for different stages of tuberculosis in ancient bone samples from Hungary. Am J Phys Anthropol 2000;113:293-304.

[10] Wicker E. Rác and Vlach people in the Northern-Bácska region during the Turkish rule [PhD dissertation]. Budapest: Eötvös Lóránd University (ELTE); 2006. p. 284.

[11] Lovász G, Schultz M, Gödde J, Bereczki Zs, Pálfi Gy, Marcsik A, Molnár E. Skeletal manifestations of infantile scurvy in a late medieval anthropological series from Hungary. Anthropol Sci 2013;121:173-85.

[12] Horváth G, Molnár E, Kovács J, Wicker E, Bérato J, Pálfi Gy. Paleopathological diagnosis and interpretation of seronegative spondylarthropathies from the 17th century. Acta Biol Szeged 1994;40:103-15.

[13] Lovász G, Bereczki Zs, Pálfi Gy, Molnár E. A possible case of echinococcosis from a late medieval series in Hungary. In: Pálfi Gy, Molnár E, Bereczki Zs, Pap I, editors. Des lésions du passé aux diagnostics modernes. Szeged University Press; 2009. p. 70-1.
[14] Pálfi Gy, Molnár E, Bérato J, Wicker E, Dutour O. Deux observations ostéoarchéologiques de spondylarthrite ankylosante et leur possible relation familiale. Rev Rhum 1996;63:160-1.

[15] Maczel M. On the traces of tuberculosis. Diagnostic criteria of tuberculous affection of the human skeleton and their application in Hungarian and French anthropological series [Ph.D. thesis]. Szeged: University of La Méditerranée, Marseille, University of Szeged, Department of Anthropology: 2003.

[16] Lovász G, Molnár E, Marcsik A. Bácsalmás-Óalmás 16-17. századi temetō paleopatológiai vizsgálatának eredményei (2001-2003-as feltárás). In: IV. Kárpát-medencei Biológiai Szimpózium. Elöadások összefoglalói: 2005. p. $153-8$.

[17] Pálfi Gy, Bereczki Zs, Ortner DJ, Dutour. Juvenile cases of skeletal tuberculosis from the Terry Anatomical collection (Smithsonian Institution, Washington, D.C., USA). Acta Biol Szeged 2012;56(1):1-12.

[18] Faerman M, Jankauskas R, Gorski A, Bercovier H, Greenblatt CL. Prevalence of human tuberculosis in a medieval population of Lithuania studied by ancient DNA analysis. Anc Biomol 1997;1:205-14.

[19] Faerman M, Jankauskas R, Gorski A, Bercovier H, Greenblatt CL Detecting Mycobacterium tuberculosis DNA in medieval skeletal remains from Lithuana. In: Pálfi Gy, Dutour O, Deák J. Hutás I, editors. Tuberculosis past and present. Golden Book Publisher Ltd; 1999. p. 371-6.

[20] Nguyen-Hieu T, Aboudharam G, Drancourt M. Mini review: dental pulp as a source for paleomicrobiology. Bull Int Assoc Paleodont 2011:5(1):48-54.

[21] Pósa A, Maixner F, Zink A, Lovász G, Molnár E, Bereczki Zs, Perrin P, Dutour O, Sola C, Pálfi Gy. Ancient human tooth samples used for TB paleomicrobial research. Acta Biol Szeged 2012;56(2):125-31.

[22] Rohland N, Siedel H, Hofreiter M. A rapid column-based ancient DNA extraction method for increased sample throughput. Mol Ecol Resour 2009 Nov. http://dx.doi.org/10.1111/j.1755-0998.2009.02824.x.

[23] Nicklisch N, Maixner F, Ganslmeier R, Friederich S, Dresely V, Meller H, Zink AR, Alt KW. Rib lesions in skeletons from early Neolithic sites in central Germany: on the trail of tuberculosis at the onset of agriculture. Am J Phys Anthropol 2012;149:391-404.

[24] Eisenach KD, Cave MD, Bates JH, Crawford JT. Polymerase chain reaction amplification of a repetitive DNA sequence specific for Mycobacterium tuberculosis. J Infect Dis 1990;161:977-81.

[25] Kamerbeek J, Schouls L, Kolk A, van Agterveld M, van Soolingen D, Kuijper S, Bunschoten A, Molhuizen H, Shaw R, Goyal M, van Embden J. Simultaneous detection and strain differentiation of Mycobacterium tuberculosis for diagnosis and epidemiology. J Clin Microbiol 1997;35:907-14.

[26] Zink A, Molnár E, Motamedi N, Pálfi G, Marcsik A, Nerlich A. Molecular history of tuberculosis from ancient mummies and skeletons. Int J Osteoarchaeol 2007:17:380-91.

[27] Neparáczki E, Török T, Pósa A, Molnár E, Lovász G, Maixner F, Zink A, Dutour O, Pálfi Gy. Preliminary results from the paleomicrobiological studies of Mycobacterium tuberculosis infection in the Bácsalmás-Óalmás anthropological series. Acta Biol Szeged 2011:55(1):41-5.

[28] Pósa A, Maixner F, Lovász G, Molnár E, Bereczki Zs, Perrin P, Zink A, Pálfi Gy. Revision of tuberculous lesions in the Bácsalmás-Óalmás series - preliminary morphological and biomolecular studies. Anthropol Anz 2012;70(1):83-100. 